\title{
Europe at the Crossroads: Is Economizing on Democracy the Future?
}

\section{Zoe Lefkofridi ${ }^{1, *}$}

${ }^{1}$ E-Mail: Zoe.Lefkofridi@sbg.ac.at

* Zoe Lefkofridi, Joint Max Weber- Jean Monnet Fellow, Robert Schuman Center for Advanced Studies, European University Institute and Assistant Professor of Comparative Politics, Dept. of Political Science, University of Salzburg, Rudolfskai 42, 5020 Austria.

Our continent has never enjoyed as much peace between states as during the European integration process that started approximately half a century ago with the Treaty of Rome. European integration promised and for a long time also delivered policy output (economic, prosperity, environmental protection, reduction of inequalities, protection of minorities, etc). Though social scientists and legal scholars have warned of the deep democratic deficits of the existing model, as long as it delivered output, the problematic citizens' input in European integration was not contested, until recently. National politicians tactfully kept the attention of publics away from Europe. Brussels, they argued, was geographically too far to concern ordinary citizens; moreover, it was too technocratic to interest them.

However, the current crisis brought to the light the thus far (hidden) inter-relationship of European and domestic policy. Compared to previous crises in European integration, this one attracted unprecedented public attention. Across the Union, very few party politicians, interest spokesmen, financial analysts, journalists or television pundits could remain indifferent to what EU officials were saying. EU-jargon moved beyond university lecture halls and parliaments and penetrated the national media and personal discussions around the continent. Citizens in all 28 EU MSs found themselves sharing anxieties and reflecting on the same issues. Electoral outcomes in one member were increasingly recognized as affecting the governing coalitions' vulnerability in other members and the European Union (EU) as a whole. Thus, EU concerns penetrated deeply (and for the first time) in the conduct and results of national parliamentary elections. What is going on in the other member states, what government officials said, what public opinion wants, became suddenly daily topics in each other's media. Through this crisis, we experience the Europeanization of the public sphere, the generation of a EU-wide discourse about Europe. I argue that at this moment when Europe is deeply politicized there is acute pressure for and firm resistance against more involvement of European 
citizens in EU decision-making. What are the promises and pitfalls of more democracy in the EU? Why should citizens be more involved in EU policy, and how could this be pursued in an information society? We pursue these questions with a focus on how information technology could contribute to this development. 